\title{
Oodgeroo Noonuccal: media snapshots of a controversial life
}

\section{Karen Fox}

Many voices swirl around a famous life. Some of this complexity can be grasped through exploring those voices that leave traces on paper or microfilm in articles, quotes and letters in the pages of major daily newspapers. This paper focuses on one famous life in particular, that of Oodgeroo Noonuccal (formerly Kath Walker). ${ }^{1}$ Such biographical snapshots of Oodgeroo, often challenged by Oodgeroo herself, reveal the lack of coherence in popular narratives of one famous life while it was still being lived. While biography can appear to impose a fixed narrative shape upon a life that was experienced as fluid and shifting by both the biographical subject and outsiders, exploring such biographical fragments re-emphasises that fluidity. Narrative fragments about Oodgeroo often appeared in large-circulation newspapers in relation to controversial events and issues, as well as in more specialised forums such as literary journals. I narrate several controversial incidents or issues Oodgeroo was involved in which featured in the pages of Australia's large-circulation daily newspapers. I contrast these narratives of controversies in Oodgeroo's life, and selected representations of her in the media, with her own views and understandings of the events and of herself. I demonstrate the way in which she both used the media to convey her message of Aboriginal rights and challenged media portrayals of herself and her work, publicly articulating her own understandings of her life.

\section{Snapshots of a controversial life: Oodgeroo in the media}

After Oodgeroo published her first collection of poems in 1964, titled We are going, she became famous more or less immediately. Her fame was based firstly on her status as the first published Aboriginal poet, but her writing was also deeply entwined with her politics and activism. She became well-known nationally to those with an interest in Aboriginal affairs, as well as to those with an interest in literature. Oodgeroo first became politically active in the 1940s through involvement with the Communist Party, and was deeply involved in the Aboriginal civil rights movement for much of her life. ${ }^{2}$ She became the secretary of the Queensland Council for the Advancement of Aborigines and Torres Strait Islanders (QCAATSI), became involved in the Federal Council (FCAATSI), and was a key figure in the campaign for the 1967 referendum, the 40th anniversary of which was celebrated in 2007. ${ }^{3}$ Her writing thus was part of her political efforts on behalf of Aboriginal people, in a period in which Aboriginal issues became more visible to the wider population. ${ }^{4}$ It is, as Kathie 
Cochrane noted, 'impossible ... to separate the poet from the activist for Aboriginal rights' ${ }^{5}$ In her terms, perhaps, Oodgeroo's writing was part of her project of educating the white population of Australia. ${ }^{6}$ Later in life, Oodgeroo returned to Stradbroke Island to live, running a cultural and education centre, Moongalba. Over 8000 children visited the centre between 1972 and 1977, staying in tents and learning Aboriginal approaches to gathering food. ${ }^{7}$

Oodgeroo's efforts for Aboriginal civil rights made her a public figure both through her poetry and through campaigning. Roberta Sykes remembered Oodgeroo having been angry about sometimes being 'misquoted' and 'betrayed' by the press. ${ }^{8}$ At the same time, the media, like her poetry, provided a channel to convey her message to the wider population. For example, several newspapers in late 1970 reported the possibility that Oodgeroo might abandon the struggle for Aboriginal rights in Australia and emigrate. She was quoted in The Australian explaining that she felt her poetry had done nothing but 'cause the Australian people to duck for cover with a guilty conscience', and she felt unable to remain and 'wait for the Aboriginal to die'. ${ }^{9}$ Described in the Sun News-Pictorial as 'an angular, tensely aggressive and dignified figure', she was reported to be making the decision because she was 'tired of her fight to get and retain dignity' for herself and for all Aboriginal people. ${ }^{10}$ The Australian reported in 1979 that she had 'given her new book to a German publisher as a protest at Australia's treatment of Aborigines' and the country's policies relating to uranium. ${ }^{11}$

A controversial issue is one which is publicly and often acrimoniously debated, and Oodgeroo lived a life dedicated to controversial issues of Aboriginal rights. Though not usually explicitly described as herself controversial, Oodgeroo was often featured in large-circulation daily newspapers in relation to controversial events or issues, several times relating to events in the conservative state of Queensland, her home state. Although she observed in an interview published in edited form in 1987 that she considered herself 'fairly conservative', it was often made clear to her that others saw her as controversial. ${ }^{12}$ For instance, she was quoted in 1986 in the Sunday Mail telling the following story:

I have not forgotten that when I was one of six finalists in the 1981 Queenslander of the Year contest [Queensland Premier Joh] Bjelke-Petersen shook the hands of the other five and ignored me. ... No Australian paper has ever printed that, although I have told plenty. ${ }^{13}$

When the organiser of the contest followed Bjelke-Petersen and persuaded him to return, he "went through the motions of the shortest handshake in history'. ${ }^{14}$ In 1984, Oodgeroo was quoted in the Sydney Morning Herald commenting on the continuing refusal of the Queensland government to change the tenure of the land at Moongalba so as to allow her to take up a Federal grant for developing an 'Aboriginal educational and cultural centre'. The refusal, she said, was 
'bloody-minded revenge' and '[t]hey are out to get me because I am an Aboriginal and because I was a thorn in their side last year'. ${ }^{15}$ As these instances suggest, Oodgeroo was a more controversial figure in Queensland than may have been the case elsewhere in Australia. Under Bjelke-Petersen from 1968 until 1987, oppressive legislation continued to circumscribe the lives of Aboriginal people, and attempts were made to suppress protest. Change came slowly and erratically, as a consequence of increasing pressure from Indigenous groups and from wider public opinion, both within Queensland and nationally. ${ }^{16}$ By the time Bjelke-Petersen ceased to be premier in 1987, the society in which Oodgeroo lived and worked had changed in crucial ways.

\section{Expo '88, the Bicentenary and becoming Oodgeroo}

One of Oodgeroo's most visible and widely commented upon gestures of protest, which she publicised through the media, related to the celebration of the Bicentenary in 1988. Made a Member of the Order of the British Empire (MBE) in 1970, Oodgeroo suggested that same year that she might take the controversial step of returning the award. ${ }^{17}$ Almost two decades later, at the end of 1987, she did so, expressing her relief after having handed the award back. ${ }^{18}$ The shifts occurring in Queensland society may also have made her decision to return the award an easier one. Oodgeroo wrote a piece for The Age explaining her reasons for returning the award, and for changing her name. As 'a protest against what the Bicentenary "celebrations" stand for', she asserted that she could "no longer, with a clear conscience, accept the English honor [sic] of the MBE', and would return it to Queen Elizabeth II, via the Queensland Governor, Sir Walter Campbell. ${ }^{19}$ She had accepted the award in the first place, she said, only after Aboriginal people with whom she discussed the offer considered that it might help to break barriers that continued to restrict Aboriginal people. ${ }^{20}$ Seeing the Bicentenary as an anniversary of '200 years of rape and carnage', she now asked, 'what is there to celebrate?' ${ }^{21}$

While it is difficult to judge accurately public responses to these actions, letters to the editor published in the Brisbane Courier-Mail provide some clues, both reflecting and contesting Queensland's conservative and repressive approach to Aboriginal affairs. One letter-writer focused on the return of the MBE, arguing that the award was granted 'by the people for her services - regardless of color [sic], politics or religion' and that Oodgeroo had 'in many ways, profited through the so-called white policy'. ${ }^{22}$ Another writer, failing to understand Oodgeroo's work and beliefs, saw her actions as a 'decision to relinquish her status in the white community', which he found 'disturbing to those Queenslanders who have admired her work and her tireless effort to uplift her race in the battle for assimilation'. ${ }^{23}$ Most letters focused on the name change. One writer sarcastically offered 'congratulations' to Oodgeroo 'for her stand against "the great white menace"' and suggested she also leave behind 'all things in her life that are white 
man-made' such as spectacles, or printing her books in English 'on a white man's invention'. ${ }^{24}$ This letter provoked several responses supporting Oodgeroo. One author questioned whether such technological advances were worth the loss of land, disease and 'bloodshed' brought by colonisation. ${ }^{25}$ The responses of Aboriginal leaders as reported in the press also varied. Gary Foley reportedly suggested that other Aboriginal people might take similar actions, and Chicka Dixon pointed out that he did not think such awards should be accepted in the first place. He had himself refused one. ${ }^{26}$ Neville Bonner, on the other hand, said that although he had no desire to celebrate the Bicentenary he would not take similar actions. ${ }^{27}$

Also in 1988, Brisbane hosted an International Exposition, or World's Fair, known as Expo '88. Oodgeroo agreed to script a short theatrical piece for Expo '88, acknowledging Aboriginal people as the first inhabitants of Australia, since she did not want this task done by an outsider. ${ }^{28}$ She was described in the Sydney Morning Herald as someone who 'personifies [the] tragedy' of division among Aboriginal people as some accepted involvement in Bicentenary celebrations and others rejected it, although the two events were actually separate. ${ }^{29}$ Oodgeroo responded that 'I am not celebrating' and that:

I don't give a stuff for Expo, or the Bicentenary. I will pick up the blood money because for the last 200 years that is all we have been given by the white people and I will use it to the best of my ability. I am giving at least 14 of my people six months' work. $^{30}$

It was later reported that Queen Elizabeth had wanted to meet Oodgeroo when she attended Expo '88. Considering it 'just a little too risky to have the Queen of the Commonwealth sipping tea with one of Australia's best-known Aboriginal activists', protocol officers presumably told the Queen Oodgeroo was not 'available', although she was in the vicinity. ${ }^{31}$ The Queen was reported to be 'furious', having found Oodgeroo's return of the MBE understandable, and being a reader of her work. ${ }^{32}$

\section{Poetry for a purpose: a controversial endeavour}

Oodgeroo's poetry also led her into controversy, this time played out in the pages of literary journals as well as newspapers. We are going was the first published collection of poetry in English by an Aboriginal writer. The book was popular, selling over 10,000 copies in seven editions. ${ }^{33}$ It became a common refrain in the popular media that Oodgeroo was the first published Aboriginal poet. As John Collins put it, she 'immediately became a public person'. 34 Oodgeroo sometimes suggested that her Aboriginality increased interest in her poetry. She commented in an interview in 1988 that We are going 'sold mainly out of curiosity value', a remark she had also made in the foreword to The dawn is at hand, her second book of poetry, in 1966. ${ }^{35}$ Ian Turner also suggested this, 
reviewing We are going for the Australian in 1964. Like the painter Albert Namatjira, he suggested, 'Mrs Walker is having a succes de surprise', which he thought reflected 'on the audience, not on the poet'. ${ }^{36}$ Even by 1971, SE Lee, writing in Southerly, described her as 'something of a curiosity (an aborigine [sic] who is also a poet)' ${ }^{37}$

Oodgeroo had joined the Realist Writers' Group in Brisbane. These groups existed throughout Australia, and aimed 'to promote the discussion and production of socialist realism in literature'. ${ }^{38}$ She had also first become politically active through a brief involvement with the Communist Party, because of the party's opposition to discrimination towards Aboriginal people, leaving when she discovered other members wished to write her speeches for her. ${ }^{39}$ As she recalled in a speech given in 1993, close to the end of her life, one of the early criticisms of her poetry when she began writing was that it was not her work, but that a 'well-known Communist' was 'writing it for her'. ${ }^{40}$ As well, she recalled:

... then when they said 'She must be writing these poems', they said

'Well, the reason why she writes good poems is because she's not a full-blood, you know. She's got white man's blood coming out in her' ${ }^{41}$

Similarly, Oodgeroo was quoted in Woman's Day/Woman's World in 1980 observing that her work was first said to be the work of a 'white person', and later, 'when it became widely known it was my poetry they said it must be the white genes giving her the brilliance'. ${ }^{42}$

Yet a further controversy surrounding Oodgeroo's poetry was literary, as many reviewers denigrated her poetic skills, sometimes suggesting that any merit her work possessed stemmed only from its message, providing a voice for Aboriginal people which was authenticated by her own Aboriginality. Reviewing We are going, poet Jill Hellyer wrote in Hemisphere in 1964 that Oodgeroo's poetry had 'considerable and definite promise' but that the collection's 'quality' was 'uneven' and that 'an attitude of preaching' sometimes weakened the poems. ${ }^{43}$ Oodgeroo's poetry was subject to considerable criticism as being mere propaganda rather than literature. ${ }^{44}$ For instance, Katharine England, in the Adelaide Advertiser, commented in 1971 that Oodgeroo 'is no poet' ${ }^{45}$ England considered that her 'forte is protest: she is a militant and dedicated fighter for social justice'. ${ }^{4}$ Likewise, Hellyer suggested Oodgeroo's focus on 'the theme of her race' was something that 'must limit her eventually unless she ceases to regard herself as a propagandist for her people', and argued that her 'pleadings are most powerful when they do not become obvious' ${ }^{47}$ In 1967, Lee's review in Southerly suggested that 'it is difficult to imagine' that even those of her poems best in poetic terms would be 'considered for publication' if it were not that 'their author happens to be an aborigine [sic] passionately concerned about a very great social wrong ... currently troubling many consciences in the white community' ${ }^{48}$ 
Oodgeroo herself at times referred to her poems as simple or as propaganda. She said in a 1990 interview, after agreeing with the interviewer that her poems were 'propaganda', that this was because of the need to get 'seventh generation white Australians' to listen, which required 'shock tactics', and she added that 'I'd rather hit them with my words than pick up a gun and shoot them' ${ }^{49}$ Judith Wright later noted that '[i]f there was one forbidden territory in poetry' in the era in which Oodgeroo began writing 'it was "propaganda and protest" literature, especially in verse' ${ }^{50}$ In this context, Oodgeroo's poetry became contested in terms of its literary merit. Moreover, defining what was political poetry was not always straightforward. In The dawn is at hand, Oodgeroo considered only one poem to be 'propaganda-like stuff', a view with which Lee emphatically disagreed. ${ }^{51}$ Confusion among literary critics about how to understand Oodgeroo's poetry suggests the variety of ways in which a life may be controversial. In these criticisms, the demand for civil rights for Aboriginal people was not explicitly questioned, as the criticisms were framed in terms of literary merit. Yet such criticisms carried the potential to suppress Oodgeroo's political message, by arguing that politics did not belong in literature, and by denying Oodgeroo literary acceptance while she used her poetry to carry her message.

\section{Representations of a 'poet and activist'}

In the first decades after the publication of We are going, Oodgeroo was often described in the print media as an 'Aboriginal poet' or 'Aboriginal poetess', rather than simply as a poet, although this description became less common in articles about her from the mid-1980s. In one article in the Australian in 1969, she was termed 'the Aboriginal poet', a description that served to emphasise representations of her as a first and a path-breaker. ${ }^{52}$ She was a strong advocate of Aboriginal rights and felt that her poetry gave a voice to Aboriginal people. In one interview she stated that she felt that the 'success' of We are going was 'inevitable ... because for the first time the Aboriginals had a voice, a written voice'. ${ }^{53}$ However, she also wished to be considered as an individual writer without such labels being applied. ${ }^{54}$ She commented that:

When I'm written up in the papers or the media or whatever, they always call me an 'Aboriginal poet'; they always tag me with that. And I don't see myself as an 'Aboriginal poet' ... I see myself as a poet who is proud to be of Aboriginal descent. ${ }^{55}$

Many other such labels were applied to her in newspaper articles across her career, shifting as she became involved in a variety of different activities. For instance, she appears to have only been described as an 'actress' around the time when she appeared in Bruce Beresford's The Fringe Dwellers (1986). Jennifer Jones has argued that Oodgeroo's 'earlier profile as "Kath Walker, poet and pan-Aboriginal activist" persistently eclipse[d] her important later work as an 
educator and children's author' ${ }^{56}$ Jones suggested that 'white Australia was not ready to acknowledge the vitality of contemporary Aboriginality that she attempted to communicate' ${ }^{57}$ Labelling Oodgeroo in these ways not only summed up her activities quickly for a skim-reading public, but potentially shaped understandings of her life and work, denying her public adoption of her own definition of herself and her activities.

Oodgeroo was often depicted in the print media as having a fiery temperament. Even in an article describing her as having 'become more a do-er than a shouter', this perception of her was evident:

Put down poet and civil rights person Kath Walker's lack of fire yesterday to one of those dreaded Melbourne colds. That's not to say the fires have gone out - with just a minimum of stoking she can flare up as she has done so often throughout her lifetime. ${ }^{58}$

Newspaper articles that profiled Oodgeroo or reported upon her work and public statements often included words such as 'fierce', 'intense', 'outspoken' or 'forthright'. Interestingly, these descriptions appeared in many newspapers across Australia, despite their different contexts and political leanings. This representation of Oodgeroo also recurred in a variety of analogies in other mediums. For instance, Shelly Neller wrote in the conservative Bulletin in 1985 that Oodgeroo 'brandishes her passionate views with the force and accuracy of a stockwhip'. ${ }^{59}$ Oodgeroo herself observed that she was 'very angry' in the years in which her early poems were written, and observed that 'I used to have to tone myself down a $\operatorname{lot}^{\prime} .{ }^{60}$ As well as being fiery, however, Oodgeroo was sometimes also described as dignified and graceful, and her dislike of violence in protest was reported on several occasions. ${ }^{61}$ When she received the award of Aboriginal of the Year in 1985, she was described by the Sun Herald as receiving it 'with her accustomed soft-spoken grace, edged with hard-nosed home truths about the lot of her race in Australia'. ${ }^{62}$ However she was portrayed, such descriptions carried baggage which could shape readers' understandings of both Oodgeroo and her message.

\section{Conclusion}

Oodgeroo's work, speeches and actions as mediated through newspaper coverage reveal many snapshots of controversy, moments when her actions and words provoked criticism and debate. Perhaps this was inevitable for one who so openly challenged the society in which she lived, who was so obviously willing to be a visible and vocal Aboriginal woman in a society with a white male norm. During her lifetime she was often represented in the media as an 'Aboriginal poet', a propagandist rather than a real poet, or a fiery activist. At her death in 1993 she was lauded as 'a great Australian', 63 'one of Australia's finest citizens', 64 'a battler' and 'a national treasure'. ${ }^{65}$ Such tributes, genuine though they may 
have been, potentially transformed her from a controversial figure, a challenger of society, to an embodiment of an idealised nation, one of its canonised heroes. One wonders what she would have had to say about that, and what controversy she would have begun.

\section{References}

Anonymous 1969, 'Aboriginal poet sees black revolt as inevitable', The Australian, 17 September: 2.

Anonymous 1970, "I won't watch the Aboriginals die out": Kath Walker talks about deserting', The Australian, 21 November: 5.

Anonymous 1970, 'Kath Walker is giving up her battle', Sun News-Pictorial, 23 November: 13.

Anonymous 1970, 'May return MBE, says native leader', The Age, 27 July: 10.

Anonymous 1971, 'Poet hits at "Black Power" violence', Sydney Morning Herald, 1 December: 11.

Anonymous 1979, 'Kath closes the book on local publishers', The Australian, 5 October: 2 .

Anonymous 1993, 'Nation mourns tenacious mother figure', The Australian, 17 September: 2 .

Aubin, Tracey 1987, 'A celebration with a bitter taste for some', Sydney Morning Herald, 18 August: 17.

Barnes, Mick 1980, 'Kath Walker and the bridge to the Dreamtime', Woman's Day/Woman's World, 13 August: 58-9.

1985, 'Kath's devoted herself to survival', Sun-Herald, 15 September: 53.

Bicknell, Graham 1977, 'Kath's fire still has heat', Daily Telegraph, 19 July: 13.

Blyth, Tracey 1987, 'Is she really serious?', Courier-Mail, 21 December: 8.

Box, RR 1987, 'Shame on us', Courier-Mail, 30 December: 8.

Cochrane, Kathie 1994, Oodgeroo, University of Queensland Press, St Lucia.

— 1994, 'Oodgeroo', in Oodgeroo, Kathie Cochrane (ed), University of Queensland Press, St Lucia: 3-158.

- 2000, 'Noonuccal, Oodgeroo', in The Oxford companion to Aboriginal art and culture, Sylvia Kleinert and Margo Neale (eds), Oxford University Press, Melbourne: 664.

Collins, John 1994a, 'A mate in publishing', Australian Literary Studies 16: 9-23. 1994b, 'Oodgeroo of the Tribe Noonuccal', Race and Class 35 April-June: 77-87. 
Craven, Rhonda 1994, 'Oodgeroo: An educator who proved one person could make a difference', Australian Literary Studies 16: 121-30.

Dwyer, Nan 1986, 'Aboriginal poet seeks peace with visit to Moscow', Sunday Mail, 21 December: 9.

— 1987, 'Support for black poet's name change', Sunday Mail, 27 December: 5.

England, Katherine 1971, 'Kath Walker: a fighter in verse', Advertiser, 1 May: 26.

Evans, Raymond 2007, A history of Queensland, Cambridge University Press, Cambridge and Port Melbourne.

Green, Jonathan 1987, 'In the blacking of a name is a struggle for a "humiliated race"', Herald, 17 December: 2.

Hamilton, Fiona 1993, 'Oodgeroo buried beneath the paperbarks: tributes flow for "Grand Old Lady"', Canberra Times, 21 September: 3.

Hellyer, Jill 1964, 'Aboriginal poet', Hemisphere, December: 17-8.

Jones, Jennifer 2004, 'Deemed unsuitable for children: the editing of Oodgeroo's Stradbroke Dreamtime', Papers, 14 May: 5-14.

Lee, SE 1967, 'Poetic fisticuffs', Southerly: 60-71.

1971, 'Old verse', Southerly: 227-40.

Lucas, M 1987, 'Shortchanged?', Courier-Mail, 28 December: 8.

Mackenzie, Ian 1987, 'Oodgeroo keeps culture alive', Courier-Mail, 29 December: 8.

McLaren, John 1996, Writing in hope and fear: Literature as politics in postwar Australia, Cambridge University Press, Cambridge.

Mitchell, Susan 1987, The Matriarchs: Twelve Australian women talk about their lives to Susan Mitchell, Penguin, Ringwood.

Monk, Sylvia 1988, 'Understanding', Courier-Mail, 5 January: 8.

Neller, Shelly 1985, 'Kath Walker, activist, artist, finds a new medium for her cause', Bulletin, 3 December: 88-90.

Noonuccal, Oodgeroo 1987, 'Why I am now Oodgeroo Noonuccal', The Age, 30 December: 11.

Noonuccal, Oodgeroo and Turcotte, Gerry 1988, 'Recording the cries of the People', in Aboriginal Culture Today, Anna Rutherford (ed), Dangaroo, Sydney: 16-30.

Paskins, Alfred 1987, 'White man's only crime', Courier-Mail, 24 December: 8. 
Roberts, Greg 1984, 'It's “bloody-minded revenge", says Kath Walker', Sydney Morning Herald, 10 May: 16.

_ 1989, 'And now to settle a royal score, by Malcolm Williamson', Sydney Morning Herald, 19 October: 3.

Rushtone, J 1987, 'Honour was deserved', Courier-Mail, 22 December: 8.

Sherman, Paul 1987, 'Understanding the name change', Courier-Mail, 23 December: 8.

Shoemaker, Adam 2004, Black words white page, ANU E Press, Canberra.

Smith, David 1993, 'Goss leads tributes to "Remarkable Australian" ', Gold Coast Bulletin, 17 September: 2.

Smith, Elizabeth 1990, 'Are you going to come back tomorrow?', The Queensland Writer, July-August: 13-16.

Sykes, Roberta B 1994, 'While my name is remembered ... ' Australian Literary Studies, 16(4): 35-41.

Turner, Ian 1964, 'Colour seeks justice', Australian, 26 September: 13.

Van Toorn, Penny 2000, 'Indigenous texts and narratives', in The Cambridge companion to Australian literature, Elizabeth Webby (ed), Cambridge University Press, Cambridge: 19-49.

Walker, Kath 1966, The dawn is at hand, Jacaranda, Brisbane.

Wright, Judith 1994, 'The poetry', in Oodgeroo, Kathie Cochrane (ed), University of Queensland Press, St Lucia: 163-183.

\section{ENDNOTES}

${ }^{1}$ I refer to her throughout as Oodgeroo, the name she chose.

2 Cochrane 1994: 17-18.

3 Cochrane 1994: 32 .

4 This point is also made by Penny Van Toorn. Van Toorn 2000: 29-30.

${ }^{5}$ Cochrane 2000: 664 .

${ }^{6}$ Several writers acknowledged after her death that her poetry was part of a mission to educate white Australians. For instance, see Craven 1994: 122.

7 Cochrane 1994: 93.

8 Sykes 1994: 38.

9 Anonymous, Australian, 21 November 1970: 5.

10 Anonymous, Sun News-Pictorial, 23 November 1970: 13.

11 Anonymous, Australian, 5 October 1979: 2 .

12 Mitchell 1987: 203.

13 Dwyer, Sunday Mail, 21 December 1986: 9.

14 Dwyer, Sunday Mail, 21 December 1986: 9.

15 Roberts, Sydney Morning Herald, 10 May 1984: 16 .

16 Evans 2007: 232 . 
17 The Age reported that she wished the National Tribal Council's requests be put in place, and quoted her suggesting that if they were not, she could write to the Queen about her concerns and return her award. Anonymous, Age, 27 July 1970: 10 .

18 Collins 1994a: 19.

19 Noonuccal, Age, 30 December 1987: 11 .

20 Noonuccal, Age, 30 December 1987: 11.

21 Noonuccal, Age, 30 December 1987: 11

22 Rushtone, Courier-Mail, 22 December 1987: 8.

23 Paskins, Courier-Mail, 24 December 1987: 8 . Oodgeroo, however, had consistently opposed assimilation, as she had made clear in a pair of poems respectively titled 'Assimilation, No!' and 'Integration, Yes!': Walker 1966: 7-8.

24 Blyth, Courier-Mail, 21 December 1987: 8.

25 Lucas, Courier-Mail, 28 December 1987: 8. Others that were supportive of Oodgeroo's name change appeared in: Box, Courier-Mail, 30 December 1987: 8; Mackenzie, Courier-Mail, 29 December 1987: 8; Monk, Courier-Mail, 5 January 1988: 8; Sherman, Courier-Mail, 23 December 1987: 8.Oodgeroo also received letters personally, reportedly telling the Courier-Mail that she had received both 'hate mail' and letters 'written to offer support' for her name change. Dwyer, Sunday Mail, 27 December 1987: 5.

26 Green, Herald, 17 December 1987: 2.

27 Green, Herald, 17 December 1987: 2.

28 Cochrane 1994: 134.

29 Aubin, Sydney Morning Herald, 18 August 1987: 17.

30 Aubin, Sydney Morning Herald, 18 August 1987: 17.

31 Roberts, Sydney Morning Herald, 19 October 1989: 3.

32 Roberts, Sydney Morning Herald, 19 October 1989: 3.

33 Cochrane 1994: 37.

34 Collins 1994b: 79.

35 Noonuccal and Turcotte 1988: 19; Walker 1966: foreword.

36 Turner, Australian, 26 September 1964: 13.

37 Lee 1971: 233.

38 McLaren 1996: 33.

39 Cochrane 1994: 17- 18.

40 Noonuccal, 'Writers of Australia, "I dips me lid"', Goossens Lecture, delivered at the Sydney Opera House, 9 June 1993, reprinted in Cochrane 1994: 229.

${ }^{41}$ Noonuccal, 'Writers of Australia, "I dips me lid"', Goossens Lecture, delivered at the Sydney Opera House, 9 June 1993, reprinted in Cochrane 1994: 229. These aspects of the controversy around her poetry were remarked on by Cochrane and by Collins. Cochrane 1994: 40; Collins 1994b: 79.

42 Barnes, Woman's Day/Woman's World, 13 August 1980: 59.

43 Hellyer 1964: 17-18.

44 Many writers have noted the dismissal of her work on literary grounds and by terming it merely propaganda. See for instance: Shoemaker 2004: 182-185.

45 England, Advertiser, 1 May 1971: 26.

46 England, Advertiser, 1 May 1971: 26.

47 Hellyer 1964: 17-18.

48 Lee 1967: 64.

49 Smith 1990: 14.

50 Wright 1994: 168.

${ }^{51}$ Walker 1966: foreword; Lee 1967: 64.

52 Anonymous, Australian, 17 September 1969: 2 . Emphasis is mine.

53 Noonuccal and Turcotte 1988: 19.

54 See Adam Shoemaker on this point. Shoemaker 2004: 188. 
55 Personal interview with Oodgeroo Noonuccal, conducted by Cliff Watego, Stradbroke Island, August 1982, quoted in Shoemaker 2004: 188.

56 Jones 2004: 5.

57 Jones 2004: 5.

58 Bicknell, Daily Telegraph, 19 July 1977: 13.

59 Neller, Bulletin, 3 December 1985: 90.

60 Smith 1990: 13-14.

61 For example: Anonymous, Sydney Morning Herald, 1 December 1971: 11.

62 Barnes, Sun-Herald, 15 September 1985: 53.

63 Queensland Premier Wayne Goss, quoted in Smith, Gold Coast Bulletin, 17 September 1993: 2.

64 Minister for Aboriginal and Torres Strait Islander Affairs Robert Tickner, quoted in Anonymous, Australian, 17 September 1993: 2.

65 Hamilton, Canberra Times, 21 September 1993: 3. 